\title{
PTK2 Gene
}

National Cancer Institute

\section{Source}

National Cancer Institute. PTK2 Gene. NCI Thesaurus. Code C24699.

This gene plays a role in apoptosis, cell motility and proliferation. 